\title{
Escultura, modernismo y Academia: interrelaciones entre la enseñanza, el discurso estético oficial y la escultura modernista en Barcelona (I888-1910)
}

\author{
Sculpture, Catalan Art Nouveau and Academy: on Teaching, Official Aesthetics \\ and Art Nouveau Sculpture in Barcelona (I888-1910)
}

Artículo recibido el 20 de mayo de 2016; devuelto para revisión el 9 de octubre de 2016; aceptado el 7 de diciembre de 20I6. http://dx.doi.org/IO.2220I/iie.I8703062e.20I7.I.25I2.

Irene Gras Valero Universidad de Barcelona-Departamento de Historia del Arte, España, igrasv@ub.edu

Cristina Rodríguez Universidad de Barcelona-Departamento de Historia del Arte, EspaSamaniego ña, cristinarodriguez@ub.edu

Líneas de investigación Simbolismo, decadentismo, modernismo y art nouveau de finales del siglo XIx y principios del siglo xx, en el ámbito europeo y catalán; mediante enfoque interdisciplinario que relaciona la pintura, la escultura y la arquitectura con la literatura y la filosofía; el trabajo de artistas catalanes en América (México, Cuba y Buenos Aires).

Lines of research Symbolism; Decadent movement; Catalan and European Modernism and late nineteenth-century Art Nouveau, through an interdisciplinary view relating painting, sculpture and architecture with literature and philosophy; the work of Catalan artists in America (Mexico, Cuba, Buenos Aires).

Publicaciones más relevantes

Cristina Rodríguez Samaniego, "Considering National Art from the Distance: Kineton Parkes and his Reflections on Contemporary Sculpture made in Spain”, Sculpture Journal, núm. 25 (2016): 8I-IoO; "Greek and French: A New Vision of the Catalan National Myth of Origin at the Beginning of the 2oth Century through Sculpture", Studies in Ethnicity and Nationalism I4, núm. I (2OI4): IOI-II8; "La educación artística en la Escuela de Bellas Artes de Barcelona durante el siglo xIx. El caso de la escultura", Arte, Individuo y Sociedad 25, núm. 3 (2013): 494-507.

Irene Gras Valero, “The Quest for Artificial Paradise: Images of Morphinomania", en Considering and Interpreting Leisure. Pastimes, Entertainments, Hobbies and Addictions in the Barcelona of 1900 (Publicacions de la Universitat de Barcelona, 20I3), 2OI-2I8; "El Pai- 
satge simbolista i la degeneració de raça”, en Arts i naturalesa: biologia i simbolisme a la Barcelona del 1900 (Publicacions Universitat de Barcelona, 2014), 65-80: "La introducció del decadentisme a Catalunya”, Revista de Catalunya, núms. 273-274 (2012): 77-99. En coautoría: Cristina Rodríguez Samaniego, Núria Aragonès Riu e Irene Gras Valero, coords., L'escultura a estudi. Iniciatives i projectes (Barcelona: Publicacions i Edicions de la Universitat de Barcelona, 20I6); Cristina Rodríguez Samaniego e Irene Gras Valero, "Artistas catalanes en la universidad argentina y chilena a principios del siglo xx", Matèria. Revista Internacional d'Art, núm. 9 (2016): I29-I47.

Resumen El presente artículo se ocupa de la relación entre la escultura pública y la Academia de Bellas Artes de Barcelona en la época de configuración del modernismo catalán. Se busca aportar una visión renovada de la academia del momento, al cuestionar la idea de que ésta fue impermeable a las corrientes innovadoras que aparecieron en el mundo occidental de finales del siglo xIx y principios del xx. El artículo aborda un enfoque poco habitual en el aspecto historiográfico, en el que el discurso estético emitido por la academia tiene un papel importante, y en el cual se propone una revisión de lo académico y del academicismo en su relación con la escultura, aplicable a otros contextos geográficos.

Palabras clave escultura; arte público; modernismo catalán; Academia de Bellas Artes.

Abstract The present article deals with the relationship between public sculpture and the Academia de Bellas Artes in Barcelona in the period of configuration of Catalan modernism. It seeks to offer a renovated vision of the Academy of the time by questioning the idea that it was impermeable to innovatory currents that appeared in the western world in the late nineteenth and early twentieth centuries. The article takes an unusual historiographical approach, in which the esthetic discourse emitted by the Academy plays an important role, and proposes a new look at academicism and the academic in its relationship to sculpture that may also be applied in other geographical contexts.

Keywords sculpture; public art; Catalan modernism; Academia de Bellas Artes. 
DOI: http://dx.doi.org/10.22201/iie.18703062e.2017.1.2592.

\author{
IRENE GRAS VALERO \\ Y CRISTINA RODRÍGUEZ SAMANIEGO \\ UNIVERSIDAD DE BARCELONA \\ DEPARTAMENTO DE HISTORIA DEL ARTE \\ ESPAÑA
}

\title{
Escultura, modernismo y Academia: \\ interrelaciones entre la enseñanza, el discurso estético oficial y la escultura modernista en Barcelona (I888-1910)
}

esulta evidente que la escultura ha sido la última de las disciplinas artís-
ticas del siglo xix en revisarse de forma crítica en el mundo occidental,
tal como advierte Carlos Reyero, ${ }^{\mathrm{I}}$ hecho que comporta la necesidad de seguir trabajando historiográficamente en dicho ámbito, sobre todo en lo que atañe a su categorización y teorización. La escultura de carácter público y monumental adolece más, si cabe, dicha limitación. Para su estudio, resulta imprescindible valorarla en su relación con las academias de bellas artes, ya que tanto como ente consultivo como educativo, éstas acompañaron y marcaron el desarrollo de la escultura pública a lo largo del siglo xIx. El presente artículo se ocupa de ahondar en el vínculo entre academia y escultura pública, y parte de un caso concreto pero paradigmático, el de la Barcelona de finales del ochocientos. Se explora un tema prácticamente inédito, que puede contribuir a la comprensión de la evolución de las corrientes estéticas que imperaron en la disciplina hacia 1900, un momento clave para la construcción del lenguaje del modernismo catalán y del art nouveau internacional, ${ }^{2}$ y en el que la

I. Carlos Reyero, El arte del siglo XIX (Barcelona: Anaya, I992), 7.

2. En el presente ensayo se usa el término modernismo como adaptación al castellano del término catalán modernisme, de uso común para aludir a la producción artística y al universo cultural de 
DOI: http://dx.doi.org/10.22201/iie.18703062e.2017.1.2592.

I 24

IRENE GRAS Y CRISTINA RODRÍGUEZ

escultura catalana llegó a su apogeo, al ser la zona peninsular que más influencia ejerció en el contexto estatal e internacional.

La escultura es, sin duda, la disciplina artística menos estudiada del modernismo, y el conocimiento que de ésta disponemos en la actualidad es mucho más limitado que el que tenemos de la arquitectura o la pintura del periodo. El hecho de que el modernismo recibiera inspiración internacional es un lugar común en la historiografía sobre esta etapa. Sin embargo, todavía no se ha analizado con detalle si dicha inspiración pudo transmitirse en el ambiente oficial de la Academia o de la Escuela de Bellas Artes de Barcelona. ${ }^{3}$ El objetivo principal del artículo es ahondar en este aspecto desde la teoría, tratando a su vez de proporcionar claves que sustenten una idea renovada de la Academia como institución, contribuyendo a la relectura que, del mundo de las academias y de sus preceptos ideológicos, se efectúa en la actualidad.

El presente artículo empieza por tratar el papel que la estatuaria pública y monumental ejerció en la configuración de la nueva imagen de la ciudad, y se señala la importancia de I888 como fecha simbólica clave en la presencia de este tipo de escultura a raíz de la celebración de la Exposición Universal de Barcelona, además de punto de partida del modernismo en el ámbito cultural. A continuación, se ofrece un breve estado de la cuestión sobre la escultura en la época del modernismo, para reflexionar posteriormente en torno a la evolución de los paradigmas estilísticos y la variedad de categorías que de forma convencional se emplean para clasificarla, en el momento de la consolidación del lenguaje estético modernista. Por último, se propone una reflexión en torno a las interrelaciones entre la escultura catalana del momento y las ideas defendidas en los discursos de los miembros de la Academia de Bellas Artes de la Ciudad Condal.

\section{Ciudad y escultura pública}

En la actualidad se antoja imposible separar la historia del arte de la de la ciudad, es decir, el hecho estético del factor social, ${ }^{4}$ por lo cual al analizar las imá-

la Cataluña del periodo I890-I9ıo. Véase más adelante la significación precisa de dicho concepto.

3. En el presente artículo utilizaremos la palabra Academia, en mayúscula, para referirnos a la Academia de Bellas Artes de Barcelona en particular, y academia, en minúsculas, para hablar de la academia como institución, en general.

4. Jean Dethier, "Por un museo imaginario", en Visiones urbanas. Europa I870-199: la ciudad del artista, la ciudad del arquitecto (Barcelona: Centro de Cultura Contemporánea, I994), I3-I4. 
genes de la ciudad que propone el artista por medio de sus obras, estaremos también explorando las diferentes miradas que acaban por configurar una determinada imagen de la propia historia.5 Se trata, por tanto, de una pluralidad de visiones interdependientes, que da lugar al establecimiento de una multiplicidad de aspectos de la misma ciudad. Éstos, a su vez, son producto del momento histórico. En este sentido, hay que tener en cuenta un hecho fundamental: el desarrollo y el auge de la escultura pública y monumental de finales del siglo XIX se encuentran intrínsecamente ligados a las transformaciones históricas y urbanísticas que se están produciendo en buena parte de las ciudades europeas y americanas. Ya sea en París, con el Plan Haussmann; en Viena, con la construcción del Ring; en la Ciudad de México, con el Paseo de la Reforma, en Buenos Aires, con el Barrio Norte y la Recoleta; o en Barcelona, con el derribo de las murallas y la aplicación del Plan Cerdà, lo que empieza a emerger es el nuevo concepto de metrópoli. Benedetto Gravagnuolo afirma con razón:

La lógica de los embellessiments, dirigida a intervenciones puntuales de recalificación de los tejidos urbanos, y la estrategia de la ciudad-servicio, fundada sobre la equilibrada difusión de las instituciones públicas, son sustituidas por la moderna idea de metrópoli, entendida como máquina urbana en la que la red de infraestructuras (de las calles y de los equipamientos) asume una inédita preeminencia jerárquica. $\mathrm{La}$ arquitectura queda férreamente subordinada al dominio del trazado viario; los propios monumentos del pasado, elegidos como puntos focales de aislados objets trouvés, reciclados como signos visuales en un paisaje metropolitano radicalmente renovado. ${ }^{6}$

El objetivo será, por tanto, el de embellecer los nuevos espacios urbanos con esculturas y monumentos que consigan reflejar las relaciones entre los propios habitantes, y entre éstos y el poder, evidenciando — para volver a la idea inicial—, que la historia de la ciudad es también la historia de su espacio público.7 Los vínculos entre la estatua y la ciudad, sin embargo, se conforman a partir de una doble vertiente: la escultura no sólo contribuye a formar entre los ciudadanos una determinada conciencia, sino que ésta proyecta asimismo una imagen

5. Teresa M. Sala, "Imágenes de la ciudad de la vida moderna. Ideales, sueños y realidades", en Barcelona 1900 (Ámsterdam: Van Gogh Museum, 2007), 15-73.

6. Benedetto Gravagnuolo, Historia del urbanismo en Europa: 1750-1960 (Madrid: Akal, 1998), 57.

7. Jordi Borja y Zaida Muxí, El espacio público: ciudad y ciudadania (Barcelona: Electa, 2003), i5. 
determinada hacia el exterior. ${ }^{8}$ En este sentido, en Cataluña se hace patente la voluntad de mostrar los ideales nacionalistas que alimentan el espíritu y la política del momento; de ahí que la ciudad se orne con un repertorio de monumentos paradigmáticos del presente y del pasado de la cultura y de la historia catalanas. Resulta significativo que el auge de la escultura conmemorativa se iniciase en I888 con la inauguración de la Exposición Universal, cuando se consolida la recuperación para la ciudadanía del Parque de la Ciutadella y se monumentaliza la zona a fin de proyectar la imagen de una Barcelona esperanzada, renovadora y cosmopolita en el ámbito internacional. Es en este marco topográfico donde encontramos la cascada del Parque, el monumento a Cristóbal Colón, el Arco del Triunfo y las figuras escultóricas que adornan el Salón de San Juan, también conocidas como la Galería de Catalanes ilustres, un conjunto de ocho esculturas exentas que representan personajes relevantes de la historia nacional: entre ellos, el conde Guifré el Pilós (840-897), el monarca Ramon Berenguer I (I035-I076), el militar Roger de Llúria (I245-I305) o el pintor y profesor de arte Antoni Viladomat (I678-I755). Se trata, en definitiva, de glorificar el pasado para poder potenciar el esplendor del presente, y señalar, al mismo tiempo, el camino del porvenir. Evidentemente, esta actitud implica, como ya seńala Carlos Reyero, el deseo de plasmar una realidad inmanente, originada en la memoria y en el sentimiento colectivos. ${ }^{9}$ Ya en el mismo i888 encontramos toda una declaración de principios en el artículo firmado por Joan Barta en La Ilustración Catalana, quien afirma que:

La idea de adornar la ciudad con monumentos y estatuas, cuando están destinados a recordar hechos o tiempos de interés para la localidad, es muy acertado y digno de elogio. [...] Así, al mismo tiempo que Barcelona demuestra que sabe continuar, y de qué manera, el movimiento artístico, literario y científico del presente siglo, con las obras motivo de este artículo, demuestra a los barceloneses que si hoy se halla en cabeza del progreso nacional, también se lo debe [este éxito] a los hombres que en épocas lejanas iluminaron o empujaron nuestra nación catalana, contribuyendo a formar el carácter de nuestro pueblo, apto para todos los progresos y fuerte para todas las empresas. ${ }^{\circ}$

8. Carlos Reyero, La escultura conmemorativa en España. La edad de oro del monumento público, I820-I9I4 (Madrid: Cátedra, I99I), 369.

9. Reyero, La escultura conmemorativa, 391.

Io. Joan Barta, "Las estatuas dels catalans ilustres", La Ilustración Catalana, núm. 195 (3I de agosto de I888): 250-25I. Texto original en catalán prenormativo: "lo pensament d'adornar la 
DOI: http://dx.doi.org/10.22201/iie.18703062e.2017.1.2592.

ESCULTURA, MODERNISMO Y ACADEMIA

Historiografía de la escultura catalana de la época del modernismo (I888-1905). Fuentes existentes y limitaciones

El interés en la escultura catalana y española de finales del XIX y principios del xx ha crecido significativamente en las dos últimas décadas. Sin embargo, son muchos los escultores que permanecen inéditos a pesar de haber desarrollado carreras de gran consistencia y haber jugado un papel esencial en el desarrollo de las artes en nuestro país. La bibliografía existente hoy día en torno a la escultura catalana del momento que nos interesa, aunque ha aumentado últimamente, es todavía demasiado sistematizadora y poco integradora, cataloga y recupera pero tiende menos a contextualizar y valorar de manera analítica. Además de las monografías específicas, reducidas a un número poco elevado de artífices, han aparecido, desde la década de los setenta, varios libros generales sobre la disciplina en el siglo XIX y principios del Xx, de los cuales daremos razón brevemente aquí. El ya citado Carlos Reyero, junto a Mireia Freixa, fue el responsable de la parte dedicada a escultura de Pintura y escultura en España, I800-I9Io, ${ }^{\text {II }}$ en el cual se agrupaban las obras de numerosos artistas decimonónicos de forma coherente y razonada. La voluntad de la obra era presentar una visión integradora de esta parte de la historia del arte de nuestro país, aunque, debido a su amplio abasto y límites de extensión, el espacio dedicado a la escultura es reducido. Lo mismo sucede con los capítulos sobre el arte español del siglo XIX aparecidos en enciclopedias, desde la participación pionera de Juan Antonio Gaya Nuño, o la de María Elena Gómez Moreno; ${ }^{12}$ fenómeno que se repite en la sugerente Historia de la pintura y la escultura del siglo XX en España de Valeriano Bozal. ${ }^{13}$

ciutat ab monuments y estátuas, quan están destináts á recordar fets ó temps d'interés per la localitat, es molt acertat y digne d'elogi [...] Axis, al mateix temps que Barcelona proba que sap seguir, y en important grau, lo moviment artístich, literari y científich del present sigle, ab las obras motiu d'aquest article, demostra als barcelonins que si avuy se troba al enfront del progrés nacional, déu també gracias als homes qu'en épocas lunyanas iluminaren ó empenyeren nostra nació catalana, contribuhint á formar lo carácter del nostre poble, apte pera tots los progressos y fort pera totas las empresas" (trad. de las autoras).

II. Carlos Reyero y Mireia Freixa, Pintura y escultura en España, I800-I9Io. Historia y evaluación crítica (Madrid: Cátedra, 1995).

I2. Juan Antonio Gaya Nuño, "Arte del siglo XIx", en Ars Hispaniae. Historia Universal del Arte Hispánico XIX (Madrid: Plus Ultra, 1958); María Elena Gómez Moreno, "Pintura y escultura española del siglo XIX”, en Summa Artis XXXV (Madrid: Espasa Calpe, 1999).

13. Valeriano Bozal, Historia de la pintura y la escultura del siglo Xx en España, vol. I (Madrid: Antonio Machado, 2013). 
DOI: http://dx.doi.org/10.22201/iie.18703062e.2017.1.2592.

$\mathrm{I} 28$ IRENE GRAS Y CRISTINA RODRÍGUEZ

Existen pocas publicaciones específicas sobre escultura española moderna y contemporánea que presenten un panorama general de la praxis de esta disciplina. Precisamente, el ya mencionado Gaya Nuño fue el responsable de Escultura española contemporánea, una de las primeras referencias en dicho ámbito. ${ }^{\mathrm{I4}}$ Esta obra no está exenta de una visión de la historia del arte propia de los años cincuenta, con una perspectiva ideológica y en detrimento del arte decimonónico. Aparecida veinte años después, La escultura española contemporánea (I800-1978) de José María Marín-Medina ${ }^{\mathrm{IS}}$ adolece de una visión del arte hecha desde la primera persona, aunque con un rigor y una amplitud que le permiten presentar un panorama mucho más completo de la escultura del siglo XIX y principios del xx. Además, Marín-Medina divide a los artífices de la Península según sus orígenes geográficos, y aborda a los catalanes por separado en función de los estilos que desarrollan. Es también uno de los primeros en establecer categorías en la escultura española reciente, pese a que la atribución de ciertos escultores a alguna de ellas se revisó posteriormente.

Otra referencia relevante en el campo que nos ocupa es el catálogo de la exposición Escultura en España, 190o-1936: un nuevo ideal figurativo, ${ }^{16}$ obra acotada a la producción escultórica del siglo xx previa a la guerra civil. Resulta interesante constatar cómo ahí el interés se centra particularmente en los escultores catalanes, pese a tener un enfoque estatal. También se evidencia una mayor presencia de los escultores en activo a partir de I9IO, dejando de lado así a los que estaban relacionados con el modernismo.

En lo tocante a la bibliografía sobre escultura catalana de la época que nos ocupa, empezaremos por indicar que no existe ninguna referencia que aborde únicamente la escultura modernista, más allá del apartado dedicado a ésta en el volumen consagrado a las artes tridimensionales de la obra El modernisme. ${ }^{17}$ Sin embargo, sí tenemos a nuestra disposición varias publicaciones que tratan la escultura catalana de los siglos XIX y Xx. Aquí se hace imprescindible destacar la labor realizada por José Manuel Infiesta, quien ha promovido sendas publicaciones homónimas, Un siglo de escultura catalana, aparecidas en 1975 y

I4. Juan Antonio Gaya Nuño, Escultura española contemporánea (Madrid: Guadarrama, 1957).

I5. José María Marín-Medina, La escultura española contemporánea (I800-1978) (Madrid:

Edarcón, 1978).

16. Escultura en España, 1900-1936: un nuevo ideal figurativo (Madrid: Mapfre, 200I).

17. El modernisme (Barcelona: L'Isard, 2002-2004). 
DOI: http://dx.doi.org/10.22201/iie.18703062e.2017.1.2592.

ESCULTURA，MODERNISMO Y ACADEMIA

2013, respectivamente. ${ }^{\mathrm{I}}$ Ambas se ocupan de escultores figurativos catalanes desde finales del siglo XIx. La primera de ellas tiene un carácter compilatorio y muy poco analítico, aunque incluye escultores prácticamente inéditos y está bien ilustrada. También cuenta con transcripciones de entrevistas hechas a los artífices, un testimonio directo que, como es evidente, aporta valor a la obra. La segunda es en realidad el catálogo de una exposición, centrada en la escultura figurativa del siglo $\mathrm{xx}$, pero que trata de contextualizar sus orígenes en el XIX e incluye a jóvenes escultores actuales, cuya obra se enraiza en la tradición. Una aportación de esta publicación de 2013 es el intento de categorizar la escultura figurativa catalana de después de la guerra civil, un campo en el que hay todavía poco trabajo hecho.

Para la comprensión de la escultura catalana de 1900, disponemos de otras tres fuentes bibliográficas fundamentales. Por una parte, la obra de Judith Subirachs, L'escultura del segle XIX a Catalunya: del romanticisme al realisme, ${ }^{19}$ en la cual la autora cruza una historia de la disciplina con estudios breves, pero interesantes, de escultores decimonónicos concretos. Esta obra tiene el valor de tratar con rigor tanto aspectos como artífices inéditos de la escultura del momento. Como fruto de una exposición de 1989 apareció Escultura catalana del segle XIX de Santiago Alcolea y Josep Termes, ${ }^{20}$ con una antología de imágenes en color y bien documentada. Finalmente, queremos destacar Estatuaria pública de Barcelona, de Manuel García-Martín, publicada en tres volúmenes. Aparecida en un momento en el que el conocimiento en dicho ámbito era parcial y poco científico, García-Martín recogió mucha de la escultura pública de la ciudad de apogeo en su momento en torno a $1900,{ }^{2 \mathrm{I}} \mathrm{y}$ formuló hipótesis sobre autorías e iconografía que han sido, en su mayor parte, corroboradas posteriormente.

De los diversos diccionarios biográficos de artistas surgidos a lo largo del siglo pasado en Espańa, es necesario destacar L'escultura catalana moderna, de

I8. José Manuel Infiesta, Un siglo de escultura catalana (Barcelona: Aura, 1975); Juan C. Bejarano, Jorge Egea y Cristina Rodríguez Samaniego, coords., Un segle d'escultura catalana (Barcelona: Fundació Les Arts i els Artistes, 2013).

19. Judith Subirachs, L'escultura del segle XIX a Catalunya: del romanticisme al realisme (Barcelona: Publicacions de l'Abadia de Montserrat, 1994).

20. Santiago Alcolea y Josep Termes, Escultura catalana del segle XIX (Barcelona: Fundació Caixa de Catalunya, 1989).

21. Manuel García-Martín, Estatuaria pública de Barcelona (Barcelona: Catalana de Gas, 1984-1986). 
DOI: http://dx.doi.org/10.22201/iie.18703062e.2017.1.2592.

I3O

IRENE GRAS Y CRISTINA RODRÍGUEZ

Feliu Elias (1926, 1928). ${ }^{22}$ Elias consagró el primer volumen de su obra a presentar un panorama reciente sobre la evolución de la escultura en Cataluña, mientras en el segundo se centró en las biografías de artistas. Al aparecer a finales de la década de 1920, el autor prestó un mayor interés a aquellos artífices que casaban con el gusto del momento, tanto modernistas como novecentista.

El hecho de que, en los últimos años, se hayan defendido tesis doctorales consagradas a la escultura catalana en torno a 1900 evidencia que el interés científico en torno al tema sigue creciendo. La tesis de Natàlia Esquinas sobre Josep Clarà y la de Lídia Català sobre Josep Campeny Santamaria son dos claros ejemplos de esta dinámica. ${ }^{23}$

De entre las fuentes que se ocupan de la escultura conmemorativa sita en espacios públicos destaca Historia y politica a través de la escultura pública: 1820I920, de Marí Carmen Lacarra y Cristina Giménez, obra que cuenta con un apartado específico consagrado al ámbito catalán; o La escultura conmemorativa en España (I820-I9I4) de Carlos Reyero. ${ }^{24}$ Podríamos añadir Monumento conmemorativo y espacio público en Iberoamérica de Rodrigo Gutiérrez Viñuales, ${ }^{25}$ un proyecto en el que el autor se interesa por la escultura conmemorativa ubicada en América Latina, e incorpora a su vez a los escultores catalanes que trabajaron en el continente, muchos de los cuales lo hicieron durante los centenarios de independencia de aquellos países y, por tanto, en fechas cercanas a 1900.

Por otra parte, en lo que atañe específicamente a Cataluña y Barcelona, Art Públic de Barcelona, aparecido en 2009 y magníficamente ilustrado, supera otros libros anteriores, como Monuments de Barcelona. ${ }^{26}$ Además, la iniciativa de Art Públic cuenta asimismo con una página web con contenidos actualizados en castellano e inglés que se revisan y aumentan periódicamente. ${ }^{27}$

22. Feliu Elias, L'escultura catalana moderna (Barcelona: Barcino, 1926-1928).

23. Natàlia Esquinas, "Josep Clarà i el seu taller", tesis doctoral (Universidad de Barcelona, 20I6); Lídia Català, "Vida i obra de l'escultor Josep Campeny Santamaria (Igualada I858-Barcelona 1922)", tesis doctoral (Universidad de Barcelona, 20I4).

24. Mari Carmen Lacarra y Cristina Giménez, Historia y política a través de la escultura pública: 1820-1920 (Zaragoza: Institución Fernando El Católico, 2003); Carlos Reyero, La escultura conmemorativa en España (I820-I9I4) (Madrid: Cátedra, 1999).

25. Rodrigo Gutiérrez Viñuales, Monumento conmemorativo y espacio público en Iberoamérica (Madrid: Cátedra, 2004).

26. Art Públic de Barcelona (Barcelona: Ajuntament de Barcelona, 2009); Monuments de Barcelona (Barcelona: L'Avenç, 1984) y Estatuaria pública de Barcelona (1984-1986).

27. Art Públic de Barcelona, consultado el is de mayo, 20I6, http://wio.bcn.cat/APPS/gmocataleg_monum/CambiaIdiomaAc.do?idioma=ca\&pagina=welcome. 
Debemos mencionar también las aportaciones realizadas en torno a los gremios y sus implicaciones en las profesiones de la escultura, que suponen un campo de estudio muy interesante para comprender los procesos en los que se basa la evolución posterior del tema en los siglos XIX y Xx. Destacaremos, como trabajos interesantes en este ámbito, la tesis doctoral de M. Lluïsa Rodríguez, "El Gremi d'escultors de Barcelona a l'últim quart del segle XviII (I785I800)", que incide en los contactos entre gremio y Academia; o Los gremios barceloneses del siglo XVIII: la estructura corporativa ante el comienzo de la revolución industrial, de Pere Molas Ribalta (1970). ${ }^{28}$

Asimismo, la bibliografía sobre las academias de bellas artes ha ido creciendo en los últimos años, a medida que renace el interés por revisar la visión monolítica ejercida sobre estas instituciones desde principios de siglo $\mathrm{XX},{ }^{29}$ especialmente en lo tocante a la docencia impartida desde éstas. El reciente congreso del Comité Español de Historiadores del Arte, celebrado en Santander en 2016 y dedicado íntegramente a la cuestión de la formación, es un claro ejemplo del nuevo interés sobre este tema en el ámbito español. ${ }^{30}$

En lo tocante a las relaciones entre escultura y academia, cabe mencionar primero los catálogos de las colecciones de escultura de las academias de la Península. Así, los trabajos de Leticia Azcue, desde su tesis doctoral (I99i) hasta publicaciones posteriores, como La escultura en la Real Academia de Bellas Artes de San Fernando. Catálogo y estudio revisten gran interés para el conocimiento del caso madrileño. ${ }^{3 \mathrm{I}}$ Para el barcelonés, véase el breve, pero sugerente

28. María Lluïsa Rodríguez, "El Gremi d'escultors de Barcelona a l'últim quart del segle XVIII (1785-1800)", tesis de licenciatura (Universidad de Barcelona, 1993); Pere Molas Ribalta, Los gremios barceloneses del siglo XVIII: la estructura corporativa ante el comienzo de la revolución industrial (Madrid: Confederación Española de Cajas de Ahorros, 1970).

29. En lo tocante a la Academia de San Carlos de México, véase la interesante obra de Eduardo Báez, Guia del Archivo de la Antigua Academia de San Carlos. 1867-1907, vol. II (México: Universidad Nacional Autónoma de México-Insituto de Investigaciones Estéticas, 1993). Sobre la academia en general y, en especial la de París, que constituyó un modelo a seguir para varias academias europeas y americanas, véase también las obras de Albert Boime, por ejemplo: The Academy and French Painting in the Nineteenth Century (Nueva York: Phaidon, 197I).

30. XXI Congreso Nacional de Historia del Arte. La formación artística: creadores-historiadoresespectadores (Santander, del 20 al 23 de septiembre de 2016).

31. Leticia Azcue, "El museo de la Real Academia de Bellas Artes de San Fernando: la escultura y la Academia", tesis doctoral (Universidad Complutense de Madrid, 2002 [1991]); Leticia Azcue, La escultura en la Real Academia de Bellas Artes de San Fernando. Catálogo y estudio (Madrid: Real Academia de Bellas Artes de San Fernando, 1994). 
DOI: http://dx.doi.org/10.22201/iie.18703062e.2017.1.2592.

trabajo de Salvador Moreno, La escultura en la Casa Lonja de Barcelona. Neoclasicismo y romanticismo académico y el más reciente y elaborado compendio de Pilar Vélez, Catàleg del Museu de Llotja. Reial Acadèmia Catalana de Belles Arts de Sant Jordi. II-Escultura i medalles. ${ }^{32}$ Otra información sobre la escultura en la Escuela de Bellas Artes de Barcelona se puede encontrar en obras dedicadas a la docencia en el centro, como Dos siglos de enseñanza artística en el principado, de Frederic Marès, o el estudio de Cristina Rodríguez Samaniego, centrado en la docencia de la escultura, "La educación artística en la Escuela de Bellas Artes de Barcelona durante el siglo XIx. El caso de la escultura". ${ }^{33}$ Realizado por la misma autora, aunque con un claro énfasis en la escultura académica de la primera mitad del siglo XIX, La imatge de l'Heroi a l'escultura catalana (I800-1850) presenta reflexiones que nos permiten establecer paralelismos con la producción escultórica finisecular. ${ }^{34}$ Por último, el estudio Acadèmia $i$ art, de Irene Gras y Mireia Freixa, aborda cuestiones relacionadas con la escultura y su vínculo con la academia de Barcelona, destacan sus reflexiones en torno a los maestros de vaciar yeso, y a ciertos artífices casi inéditos como los hermanos Vallmitjana y los Oslé. ${ }^{5}$

\section{Escultura en la Academia y academia en la escultura}

La Academia Provincial de Bellas Artes de Barcelona jugó un papel interesante en la génesis y en la articulación de la nueva imagen de la ciudad que se

32. Salvador Moreno, La escultura en la Casa Lonja de Barcelona. Neoclasicismo y romanticismo académico: discurso de ingreso del Académico electo Ilmo. Sr. Salvador Moreno, leido (Barcelona: Reial Acadèmia Catalana de Belles Arts de Sant Jordi, 1983); Pilar Vélez, Catàleg del Museu de Llotja. Reial Acadèmia Catalana de Belles Arts de Sant Jordi. II-Escultura i medalles (Barcelona: Reial Acadèmia Catalana de Belles Arts de Sant Jordi, 20oI).

33. Frederic Marès, Dos siglos de enseñanza atística en el principado (Barcelona: Reial Acadèmia Catalana de Belles Arts de Sant Jordi, 1964); Cristina Rodríguez Samaniego, "La educación artística en la Escuela de Bellas Artes de Barcelona durante el siglo XIx. El caso de la escultura", Arte, Individuo y Sociedad 25, núm. 3 (2013): 495-508 (http://revistas.ucm.es/index.php/ARIs/ article/view/40566).

34. Jorge Egea y Cristina Rodríguez Samaniego, La imatge de l'Heroi a l'escultura catalana (I800-1850)/The Image of Heroe in Catalan Sculpture (I800-1850) (Barcelona: Dux Editorial, 2013).

35. Irene Gras Valero y Mireia Freixa, coords., Acadèmia $i$ art. Dinàmiques, transferències $i$ significació a l'època moderna i contemporània (Publicaciones i Edicions de la Universitat de Barcelona, 2016). 
produjo durante la segunda mitad del siglo xIx y que se proyectó, en términos escultóricos, con motivo de la Exposición Universal de i888. La Academia quedó instaurada en I849, en virtud del Real Decreto del 3I de octubre de aquel año. Tardía en el contexto de Espańa — sobre todo, si tenemos en cuenta el volumen demográfico de la ciudad y su situación económica一, sustituyó a la Junta Particular de Comercio en el control de la Escuela de Bellas Artes, que ésta había puesto en funcionamiento en enero de $1775 .{ }^{36} \mathrm{El}$ cambio tuvo consecuencias sustanciales para la Escuela, ya que vio reorganizados y modernizados desde su estructura hasta los reglamentos y programas docentes. ${ }^{37}$

En el transcurso de la segunda mitad del siglo xIX, la importancia estratégica de la Academia en el contexto artístico de la ciudad y de su área de influencia fue muy alta. Por un lado, velaba por el buen funcionamiento de la Escuela y tomaba parte en las decisiones relativas a éste, a las relaciones externas e internas, al profesorado y alumnado. La Escuela era la única oficial y pública en Barcelona y, aunque existieran centros alternativos, éstos no pudieron compararse a ella ni por cantidad de estudiantes ni por trayectoria..$^{38}$ Por el otro, era un órgano consultivo en temas artísticos, y de gran relevancia. Como es sabido, los académicos formaban parte de comisiones dedicadas a juzgar la idoneidad de las obras artísticas de carácter público que se tenían que llevar a cabo en la ciudad y cercanías. Si procedía, la Comisión dictaminaba la aprobación del proyecto o si requería que se hicieran modificaciones, recaía en la Academia la decisión final. Para efectos prácticos, el hecho se traducía en que ésta autorizaba y supervisaba la realización de obras en la ciudad y provincia, desde edificaciones hasta decoraciones escultóricas, pasando por trazado de calles y plazas y la ejecución de pinturas ornamentales, aunque los proyectos de envergadura a menudo se sometían a comisiones de la Academia de San Fernando en Madrid. Para

36. Un tema ya tratado por diversas fuentes. Véase César Martinell, La Escuela de la Lonja en la vida artística barcelonesa (Barcelona: Escuela de Artes y Oficios Artísticos de Barcelona, I95I); Manuel Ruiz Ortega, La escuela gratuita de diseño de Barcelona. I775-1808 (Barcelona: Biblioteca de Cataluña-Unidad Gráfica, 1999).

37. Véase la visualización interactiva Professors i assignatures de l'Escola de Belles Arts de Barcelona (I850-1900), consultado el Is de mayo de 20I6, http://www.ub.edu/gracmon/docs/professors-llotja/.

38. Antes de la proliferación de academias privadas que se produjo hacia I900 y que ha sido ya estudiada, entre otros, por Francesc Fontbona en La crisis del modernismo artístico (Barcelona: Curial, 1975), en I88I se fundó el Real Círculo Artístico, una alternativa interesante a los estudios oficiales, que tomaría fuerza hacia 1900. 
DOI: http://dx.doi.org/10.22201/iie.18703062e.2017.1.2592.

el caso concreto que nos ocupa, los dictámenes relativos a las obras escultóricas en el espacio de la Exposición Universal de I888 revisten gran interés.

Así pues, la Academia, gracias a sus atribuciones, ejercía su influencia sobre el universo artístico de Barcelona, integraba en su cuerpo docente a artistas destacados, formaba a las nuevas generaciones que anhelaban un diploma oficial, y enmarcaba la producción artística. En vísperas de la eclosión del modernismo, la Academia aún poseía estas prerrogativas, que no perdería del todo hasta la reforma que sufrieron la Escuela y la Academia en 1900, que desembocó en la separación oficial entre las dos entidades. ${ }^{39}$ Este hecho favoreció el declive posterior de la Academia, el cual quedó limitado a órgano consultivo con cada vez menos fuerza y trascendencia..$^{\circ}$

Sin embargo, durante los primeros años del siglo xx, la separación se estaba todavía consolidando, y la injerencia de la Academia en la Escuela era un hecho, que ponían de manifiesto, entre otras cosas, la financiación por parte de la primera de los premios y bolsas de la Escuela.

Entre los nuevos retos de la historiografía del arte actual se encuentra el de releer y repensar las academias como instituciones y el academicismo como concepto. Huelga recordar como, desde mediados del siglo xx, el adjetivo "académico" a menudo se empleaba como sinónimo de mecánico, repetitivo. El arte académico era, por tanto, el que se producía siguiendo los preceptos de una institución de este tipo y se hacía respondiendo unos criterios objetivos, uniformes y sin aportar innovación ni formal ni estética. A grandes rasgos, se solía denominar académica a la escultura que seguía los patrones formales neoclásicos, aunque ya no mantuviera la vocación ética propia de la época ilustrada que vio nacer el movimiento. A partir de las décadas de los setenta y ochenta, cuando la historia del arte comenzó a entenderse no sólo como historia del objeto, sino también como historia de las ideas teóricas y culturales, se consolidó el modo de presentar la evolución con base en oposiciones. Esto generó lecturas nuevas sustentadas en teorías de la representación, la autoridad cultural

39. Véase Escuela Superior de Artes é Industrias y Bellas Artes de Barcelona, Memoria de la Reorganización que cumpliendo el reglamento eleva al Ilmo. Sr. Subsecretario de Instrucción Pública y Bellas Artes el director de la Escuela D. Leopoldo Soler y Pérez (Barcelona: Henrich y Cia, 1903).

40. Véase la cronología interactiva Cronologia Llotja. Esdeveniments clau de la història de l'Escola i l'Acadèmia de Belles Arts de Barcelona, consultado el Is de mayo, 2016, http://www.ub.edu/ gracmon/docs/crono-llotja/. 
y el significado visual. ${ }^{4 \mathrm{I}}$ El proceso de revisión de las academias y del academicismo continúa hoy día siguiendo la línea iniciada por Nikolaus Pevsner. ${ }^{42}$

Conforme profundizamos en el estudio de la academia y de la Escuela de Bellas Artes de Barcelona y analizamos sus artífices, nos damos cuenta de que la visión que consideraba el mundo académico como inmóvil y único no se sostiene. ${ }^{43}$ Lo que hay que revisar es, precisamente, la idea de que en la academia sólo impera un único posicionamiento, reaccionario ante la novedad y las tendencias que tratan de transformar el arte y la cultura del momento. Es necesario, pues, ir más allá de las tradicionales generalizaciones y tener en cuenta una realidad más compleja, la cual puede manifestarse en la trayectoria de los propios artistas.

De hecho, uno de los elementos que mejor nos ayudan a defender esta teoría son los discursos, efectuados por los académicos y posteriormente impresos para su publicación, hechos con motivo de aceptación de cargos, inauguración de cursos escolares o como consejo a alumnos premiados con bolsas de viaje. Éste es un material poco explorado. ${ }^{44}$ Como tipología literaria, los discursos se empezaron a generalizar en las academias de arte durante el siglo XVIII. En el aspecto formal, en el caso de Barcelona, se trata de un texto más bien corto - de extensión máxima de cuarenta páginas—, escrito siempre en primera persona y fundamentalmente dirigido a un público muy concreto, en el caso que nos ocupa, a los alumnos y al claustro de profesores. Cabe añadir que los

4I. Entre estos autores, véase a Clement Greenberg, Arte y cultura: ensayos críticos, trad. G. Beramendi (Barcelona: Gustavo Gili, 1979); y Pierre Bourdieu, Las reglas del arte: génesis y estructura del campo literario, trad. Thomas Kauf (Barcelona: Anagrama, 1997).

42. Nikolaus Pevsner, Academias de arte: pasado y presente, trad. Margarita Ballarín (Madrid: Cátedra, 1982). Para mayores datos sobre el proceso actual de revisión de la Academia y el academicismo, véase Rafael Cardoso Denis y Colin Trodd, eds., Art and the Academy in the Nineteenth Century (Manchester University Press, 2000).

43. Gras Valero y Freixa, coords., Academia i Art. Dinàmiques, transferències i significació a l'època moderna i contemporània.

44. Destacaremos, sin embargo, la aportación de Mireia Freixa, En el decurs del discurs, una aproximació a la història del pensament estètic a l'Acadèmia de Belles Arts (I856-1904): discurs d'ingrés de l'acadèmica electa Il-lma. Sra. Dra. Mireia Freixa i Serra, llegit a la sala d'actes de l'Acadèmia el 20 de febrer del 2008: discurs de contesta de l'acadèmica numerària Il.lma. Sra. Dra. Pilar Vélez (Barcelona: Reial Acadèmia Catalana de Belles Arts de Sant Jordi, 2007). 
DOI: http://dx.doi.org/10.22201/iie.18703062e.2017.1.2592.

I36

IRENE GRAS Y CRISTINA RODRÍGUEZ

discursos se publicaban, o bien de manera independiente, o bien se incluían en las actas de las sesiones públicas. 45

Lo que ponen de manifiesto los discursos del cambio de siglo es que, en el seno de la Academia y de la Escuela, las posiciones de sus miembros eran ricas y variadas. Lejos de presentar una mirada uniforme del arte y de su práctica, las voces que se alzan lo hacen desde diferentes puntos de vista, con opiniones diversas sobre el presente y el futuro de las artes en Cataluña y, lo que es aún más interesante, sobre la escultura en la ciudad. En última instancia, este material permite cuestionar la idea de que la Academia fue impermeable al modernismo y a otras corrientes innovadoras que aparecieron en la Cataluńa de finales del siglo XIX y principios del Xx. Como veremos a continuación, el estudio de estas fuentes evidencia que en la Academia existió un interés por las propuestas estéticas más innovadoras procedentes de Europa, como por ejemplo el simbolismo, corriente que, como veremos, terminó caracterizando parte de la práctica artística del modernismo catalán, y que se manifestó también en la escultura del momento sita en el espacio público. Dicho interés, dentro del ámbito académico, se tradujo en diversos discursos que muestran, por un lado, la adhesión a determinados valores propugnados por dicha corriente idealista-simbolista — pese a considerarlos e interpretarlos desde un punto de vista más bien conservador - $y$, por otro, la recuperación de los ideales románticos nazarenos, innegablemente relacionados con el idealismo finisecular.

De entre los discursos formulados por académicos profesores en la Barcelona de la época que nos ocupa, hay tan sólo el de un escultor, Pere Carbonell i Huguet (1855-1927), hecho en $1905 .{ }^{46}$ Sin embargo, debemos recordar que el alcance de los discursos entonces no solía limitarse a una disciplina o a un aspecto en concreto, sino que tenía la vocación de ser transversal y universal. Como hemos mencionado con anterioridad, se trata de fuentes prácticamente inéditas, que nos permiten explorar bajo prismas nuevos la escultura del momento. Nos hemos centrado en los profesores académicos únicamente por la incidencia directa de su pensamiento en la formación de los nuevos

45. Irene Gras Valero y Mireia Freixa, "El pensament estètic a través dels discursos de l'Acadèmia (I89I-I906): la recuperació del romanticisme i la recepció del corrent idealista simbolista”, en Gras Valero y Freixa, coords., Acadèmia i art. Dinàmiques, transferències i significació a l'època moderna i contemporània, I37- I53.

46. Academia Provincial de Bellas Artes de Barcelona (АРвваAв), Discurso leido por el Académico D. Pedro Carbonell y Huguet en la sesión pública celebrada el día I6 de abril de Igos (Barcelona: Imprenta Barcelonesa, 1905). 
DOI: http://dx.doi.org/10.22201/iie.18703062e.2017.1.2592.

ESCULTURA，MODERNISMO Y ACADEMIA

artistas y por su singular injerencia en la praxis artística de la época. A continuación, proponemos una reflexión en torno a la escultura catalana, en la que se interrelacionan proyectos concretos y discursos académicos, en el marco de construcción del lenguaje estilístico del modernismo.

\section{La configuración de la escultura modernista catalana (I888-19I0) y su relación con los discursos académicos}

\section{Modernismo y simbolismo: análisis de conceptos}

La denominación y caracterización de las propuestas escultóricas de finales del siglo xIx y comienzos del xx supone cierta problemática, y es sin duda una cuestión que merece una atención especial en el presente artículo, dado el tema que nos ocupa. La falta de precisión y la indefinición en este campo no son sólo propias del caso catalán, aunque quizá sea en éste en el que supone más dificultades, debido al volumen y la relevancia de su producción, una cuestión sobre la que ya han alertado varios expertos. ${ }^{47}$ Evidentemente, como señalara Judith Subirachs, cuando decidimos estudiar las manifestaciones artísticas o culturales de un periodo concreto, lo que nos encontramos no es una sucesión de estilos sino una yuxtaposición de tendencias, ${ }^{48}$ a pesar de que, por supuesto, unas puedan predominar temporalmente sobre otras. En este sentido, el conjunto de esculturas presentado en la Exposición de i888 es significativo, porque en su programa escultórico convive un realismo a veces de carácter anecdótico, con otros proyectos, ya impregnados de idealismo simbolista; un reflejo de la diversidad inherente a la escultura de la época.

La reflexión teórica en torno a la corriente simbolista propiamente dicha, aludida con estos términos exactos, no se consolida sino hasta ya entrado el siglo xx. Y resulta de especial interés aquí, atendiendo al hecho de que el simbolismo fue una tendencia clave en la consolidación del modernismo catalán, como han apuntado varios expertos. ${ }^{49}$

47. AрввAAB, I4I. Véase también Reyero, La escultura conmemorativa, 77; Mercè Doñate, "L'escultura modernista”, en El Modernisme, vol. I (Barcelona: Olimpiada Cultural-Lunwerg Editores, 1990), I83-I84; y Mercè Dońate, "L'escultura de col-leccionisme", en El Modernisme. Vol. IV. Les arts tridimensionals. La critica del modernisme (Barcelona: Isard, 2003), 13-32.

48. Subirachs, L'escultura del segle XIX en Catalunya, 28.

49. Doñate, "L' escultura de col.leccionisme", 20. 
Cabe señalar que el modernismo propiamente dicho debe entenderse como un movimiento amplio que aspiraba a la renovación de todas las manifestaciones de la cultura catalana; no únicamente como una "estética" determinada o un "estilo". Desde ese punto de vista, hablaríamos del modernismo como "actitud" o "ideología", caracterizada por un afán de cosmopolitismo, de transgresión y de novedad, por una parte, pero también de la voluntad de recuperar las raíces originales catalanas, y, por tanto, de reafirmación de la propia identidad nacional. ${ }^{50}$ Concebido como movimiento artístico-literario, el modernismo reuniría en su seno todas aquellas manifestaciones estéticas que contribuyeran así a la transformación de la cultura, ${ }^{5 \mathrm{I}}$ sin identificarse, en principio, con una de ellas en concreto..$^{52}$ De tal modo que, si bien es cierto que el modernismo aspira a "la construcción de una sociedad catalana con conciencia propia, que se ha de diferenciar de la tradición castellana para reafirmar la propia identidad como pueblo y como pueblo europeo, inmerso en la modernidad social y artística", se deben distinguir en él dos tipos de actitudes: "una regeneradora, más estrictamente militante o social y políticamente preocupada, y una decadentista o simbolista que

50. Esta dicotomía se hace patente en las mismas fuentes de la época. Así por ejemplo, encontramos artículos donde se defiende la voluntad de "ser modernos; reanimarnos dentro de la unión con el alma europea sin que se absorba la nuestra; y es por eso que nos dirigimos sobre todo a Francia" (texto en catalán prenormativo: "esser moderns; reanimar-nos dins la comunió ab l'ànima europea-sense absorbir-hi la nostra; i per això és sobre tot a França que nosaltres ens dirigim”) [L. Xavier de Ricard, “Decreixença de la cultura francesa?”, Pèl \& Ploma, vol. III, núm. I95 (08-I9OI):94-95], pero también otros en los cuales se insiste en no perder de vista la propia identidad: "Pues bien, ahora que afortunadamente estamos encaminados hacia una sólida regeneración artística, ha llegado el momento de que los artistas catalanes levanten la cabeza y vean que en nuestra tierra se puede hacer también el arte puro, que debiéramos desarrollar nosotros, sin esperar que vengan músicos extranjeros para la realización de tan hermosas manifestaciones y procurando al contrario que nos encontrasen ya con vida propia, contribuyendo ellos solo al mejor desarrollo, pero no teniendo que trazarnos la dirección general" [Juan Gay, "Vicent d'Indy", Luz, núm. 8 (I2-I898): s. p.].

5I. "Buscamos un nuevo arte para nuestra nueva vida [...] porque realmente se forma un mundo nuevo, una sociedad nueva, y el arte, que es hijo de la conciencia humana, cambia cuando éste cambia también", proclamará Domenech, "La evolución del arte moderno", Pèl \& Ploma III, núm. 88 (mayo, I902): 369-370.

52. Véase Joan Lluís Marfany, Aspectes del modernisme (Barcelona: Curial, 1984); Enric Bou, Poesia i sistema: La revolució simbolista a Catalunya (Barcelona: Empúries, 1989), 204; Joaquim Molas, "El modernisme i les seves tensions", Serra d'Or, núm. I35 (diciembre, I970): 45-52; o Eliseu Trenc, "El modernisme es un estil?”, Revista de Catalunya, núm. 5 (febrero, 1987): I26-I34. 
centra su revuelta en el desarrollo de una nueva estética subversiva". ${ }^{33}$ Sin embargo, durante la última década del siglo xIx, el modernismo llegó a identificarse con una de esas tendencias en concreto, la idealista-simbolista, y dio origen a una confusión que se prolongaría durante muchos años. ${ }^{54}$

El ámbito de la escultura no pudo escapar de dicha confusión. Por ese motivo, Alexandre Cirici Pellicer nos dice que el modernismo escultórico "consiste en una fase de influencia de Rodin, por una parte, y por otra, del cultivo de las formas fundidas, las actitudes extáticas, los cuerpos delgados, casi enfermizos, con frecuencia los ojos cerrados, los cabellos huecos". 55

Hay que añadir que Cirici contrapone este nuevo estilo, "lírico" y "elegante", al "formalismo" del arte "académico", y reconoce sin embargo que un mismo artista podía cultivar ambas soluciones a lo largo de su trayectoria artística. Otro aspecto a considerar es el hecho de que, dentro del mismo modernismo, el autor distingue dos vertientes: la llamada "ala blanca" y el "ala negra". Si la primera sería característica de un simbolismo de carácter más idealista (cultivada por Miquel Blay, Enric Clarasó o Josep Limona) la segunda constituiría una "faceta negra, la tendencia a sumirse en la miseria de la concreción humana para solidarizarse con el dolor de la vida realmente tangible", más propia de un escultor como Carles Mani. ${ }^{56}$ Sea como fuere, es importante tener en cuenta algo que resultó clave en el impulso de las ansias de renovación estética en el ámbito escultórico: la influencia de Aguste Rodin (I840-19I7). A pesar de que éste ya hacía tiempo que se conocía en Cataluña a través de artículos y reproducciones de su obra en publicaciones periódicas, la retrospectiva dedicada a Rodin en París en 1900 supuso un punto de inflexión en el conocimiento y la posterior introducción de las fórmulas más innovadoras en el ámbito catalán, aunque en Francia el simbolismo ya se encontrara en pleno declive. Sin esta influencia es imposible entender Eva (1904) de Clarasó, Éxtasis de Josep Clarà

53. Marisa Siguan, La recepción de Ibsen y Hauptmann en el modernismo catalán (Barcelona: PPU, 1990), II y I2

54. Joan Lluís Marfany, Aspectes del modernisme, 20-44. Como explica el autor, a raíz de la celebración, en I894, de la tercera de las llamadas Fiestas Modernistas, la cual se caracterizó por poseer un carácter acusadamente decadentista, el sector más crítico y tradicional aprovechó la ocasión para identificar el modernismo con el decadentismo, puesto que dicha tendencia se prestaba mucho mejor a la crítica y a la parodia que no a la corriente vitalista de influencia nietzscheana, que también se encontraba incorporada en dicho movimiento.

55. Alexandre Cirici Pellicer, El arte modernista catalán (Barcelona: Aymà, 195I), I50.

56. Cirici Pellicer, El arte modernista catalán, I63. 
DOI: http://dx.doi.org/10.22201/iie.18703062e.2017.1.2592.

I40

IRENE GRAS Y CRISTINA RODRÍGUEZ

(I878-1958)57 o el Desconsuelo (original de 1903, colocación 1917) de Llimona. No obstante hay que recordar que durante el mismo periodo pervivió el realismo de carácter anecdótico, tal como nos muestran las obras de Josep Montserrat (I860-1923) o Joan Piqué (I877-1924), entre tantos otros.

Con todo ello hay que señalar lo siguiente: si bien es cierto que en el modernismo existían diversas tendencias estéticas y que, por tanto, resulta erróneo identificarlo exclusivamente con una de ellas en particular, es importante reconocer que la corriente idealista-simbolista predominó por encima de las demás. Y no sólo eso, sino que fue en ésta donde se perpetraron las fórmulas consideradas más experimentales. ${ }^{58}$ Por este motivo es necesario profundizar un poco más en ella. Durante el proceso de penetración en Cataluña del simbolismo, 1891 fue un año especialmente significativo. En la Exposición General de Bellas Artes de Barcelona pudo constatarse la presencia del idealismo artístico. ${ }^{59}$ Es también en I89I cuando tuvo lugar la segunda exposición, en la Sala Parés de la Ciudad Condal, de las obras de Ramon Casas, Santiago Rusiñol y Enric Clarasó, en la que, según el crítico Raimon Casellas, se podía percibir un arte surgido de la "emoción", un arte "sugestivo", que partía de la realidad para mostrar lo que el artista sentía con mayor "intensidad". ${ }^{\circ}$ En el certamen Clarasó presentó la obra Oración, en la que representa a una joven que prefigura en su rostro la introspección que caracterizará algunas de sus obras más simbolistas. Sólo unos años después realizaría Poncella rota, que el mismo Casellas describiría con estas ilustrativas palabras: [a través de esta obra del artista] "ha llegado, tal vez inconsciente, a un más allá de inesperada trascendencia [...] ha logrado remontarse la voluntad a fénomenos psíquicos de la misma derivados para crear como un símbolo enfermizo y febril de nuestra alma contemporánea". ${ }^{61}$

Sin duda nos encontramos ya en las puertas del simbolismo, corriente que irrumpiría de manera oficial y definitiva en septiembre de I893, durante la celebración de la Segunda de las Fiestas Modernistas en Sitges. Sin embargo, en el ámbito específicamente escultórico, los estudios más bien hablan de "idealismo" a la hora de designar determinadas obras de este periodo de finales de

57. Sobre Josep Clarà, véase Cristina Rodríguez Samaniego e Irene Gras Valero, Al taller de Josep Clarà. Els guixos d'un escultor irrepetible (Barcelona: Fundació Les Arts i Els Artistes, 2016).

58. Reyero y Freixa, Escultura y pintura, 262.

59. Doñate, "L'escultura de col.leccionisme", I4-15.

6o. Raimon Casellas, "Exposición de pinturas. Rusiñol. Casas", L’Avenç, núm. II (noviembre, I89I): 334-343.

6I. Raimon Casellas, "Bellas Artes. Enrique Clarassó", La Vanguardia, núm. 3257 (junio, I892): 4. 
DOI: http://dx.doi.org/10.22201/iie.18703062e.2017.1.2592.

ESCULTURA，MODERNISMO Y ACADEMIA

siglo, y al destacar que las renovaciones en la escultura, materializadas en la adopción de una estética y de unos motivos plenamente simbolistas, llegaron más tarde que en el campo pictórico. ${ }^{62}$ Durante estos años se mantuvieron las fórmulas más tradicionales relacionadas con el realismo de carácter anecdótico, pero varios autores se encaminaron mediante determinadas obras hacia un idealismo sugerente y moralizante. Es sobradamente conocido el papel ejercido por el Cercle Artístic de Sant Lluc en la configuración de este estilo, ${ }^{63}$ aunque quizá no lo es tanto el que jugó la Academia de Barcelona.

\section{El romanticismo nazareno en los discursos de la Academia y su incidencia en el idealismo finisecular}

Dados los lazos establecidos entre el movimiento romántico y la tendencia idealista-simbolista, fruto de la significativa influencia que el primero ejerció sobre la segunda, resulta de gran importancia sopesar la revalorización de los ideales románticos por parte de la Academia. ${ }^{64}$ De hecho, cuando tiene lugar esta recuperación, en Cataluña ya hacía algunos años que comenzaba a arraigar la corriente idealista dentro del panorama de las artes plásticas. Será Felip Bertran i d'Amat (I835-19II) quien, en el discurso Del origen y doctrinas de la escuela romántica y de la participación que tuvieron en el adelantamiento de las bellas artes en esta capital los señores D. Manuel y D. Pablo Milá i Fontanals y D. Claudio Lorenzale, defendido el I2 de abril de I89I, pondrá de manifiesto dicho interés por el romanticismo, en una clave modernizada y en el contexto de la concreción del lenguaje estético del modernismo. ${ }^{65}$

62. Francesc Fontbona, "L'època del modernisme", en Història de l'Art Català: del modernisme al noucentisme, vol. VII (Barcelona: Ediciones 62, 1985), 50; Subirachs, L'escultura del segle XIX, I70; o Dońate, "L'escultura de col.leccionisme", I3; Carlos Reyero y Mireia Freixa, por el contrario, argumentan que la escultura simbolista nace en paralelo al simbolismo pictórico, hacia i895. Véase Reyero y Freixa, Pintura y escultura en España, I800-I919, 392.

63. Barbara Marchi, "Cercle Artístic de Sant Lluc 1893-2009: història d'una institució referent per a la cultura barcelonina”, tesis doctoral (Universitat de Barcelona, 20II).

64. Para una visión general sobre algunos aspectos importantes del nazarenismo escultórico de alcance internacional, véase la obra de Stefano Grandesso, Berthel Thorvaldsen (I770-I884) (Cinisello Balsamo: Silvana, 20I5).

65. Felip Bertran i d'Amat, Del origen y doctrinas de la escuela romántica y de la participación que tuvieron en el adelantamiento de las bellas artes en esta capital los señores D. Manuel y D. Pablo Milà y Fontanals y D. Claudio Lorenzale (Barcelona: Imprenta Barcelonesa, I89I). 
DOI: http://dx.doi.org/10.22201/iie.18703062e.2017.1.2592.

I42

IRENE GRAS Y CRISTINA RODRÍGUEZ

Como se evidencia en el mismo título, el discurso se origina a partir de la conmemoración que la Academia dedica a la memoria de tres de sus miembros más distinguidos del periodo romántico: Pau Milà i Fontanals (I8IO-I883), Manuel Milà i Fontanals (I8I8-I884) y Claudio Lorenzale (I8I5-I889). Por tanto, en un primer momento, se plantea como triple necrológica. Sin embargo, Bertran enseguida pone de relieve el vínculo que une a estas tres figuras: el hecho de haberse convertido en herederos de las doctrinas del primer romanticismo. Por este motivo, antes de hablar extensamente sobre la vida y la obra de los académicos mencionados, Bertran divide en dos partes su discurso y convierte la primera en un cuidadoso estudio dedicado al movimiento romántico, a fin de profundizar en los procesos que dan lugar a su formación, determinar sus rasgos característicos y, finalmente, llevar a cabo un seguimiento de su evolución. Hay que señalar que el historiador presenta el romanticismo en calidad de corriente germánica y antifrancesa, originada en buena parte como revuelta contra los preceptos neoclásicos, el barroquismo y la pintura galante. Como reacción, pues, al espíritu francés de la Ilustración —utópico, cosmopolita y no seguidor del cristianismo-, en Alemania se potencia la individualidad nacional y el ideal cristiano, rasgos que constituyen los fundamentos de este primer romanticismo. Tanto el presente discurso de Bertran, como el que pocos años más tarde pronunciaría el obispo Josep Torras i Bages (I846-1916) se esfuerzan por destacar este modelo de virtuosismo cristiano que tiene como ideales eternos el anhelo de justicia, verdad y belleza, y que otorga al arte una finalidad claramente religiosa. Éste es, de hecho, uno de los motivos principales de recuperación del primitivo romanticismo, los valores sobre los que se sustenta y que defiende: la afirmación de la individualidad nacional y, sobre todo, de la fe y de la moral cristianas. Es a partir de éstas que tiene lugar el tránsito entre una religión de carácter materialista y otra más espiritual, y se produce el apoyo hacia la subjetividad y la expresión del sentimiento en el arte.

Determinados el origen y los rasgos esenciales del movimiento romántico, Bertran hace un recorrido por la extensión que alcanzó toda Europa y por tanto, por su evolución. $Y$ es a partir de este momento que el autor comienza a diferenciar tendencias. Aunque se refiere al pensamiento de uno de sus herederos, el ya mencionado Manuel Milà i Fontanals, Bertran distingue entre una corriente espiritualista y restauradora y otra individualista y escéptica, que poco a poco deriva hacia una estética de "lo feo". Dentro del primero, pues, sitúa al malogrado Wilhelm Heinrich Wackenroder (1773-I798), a Johann Friedrich Overbeck (I789-1869) y su círculo (Cornelius, Schadow...), e, incluso, 
a Jean-Auguste-Dominique Ingres (I780-I867), de quien elogia la corrección en el dibujo y la composición, y el cultivo de la pintura religiosa. Este último artista constituye una excepción dentro del ámbito francés, ya que cuando el romanticismo llegó a Francia, explica Bertran, se encontró con los derivados ideológicos de la revolución y la falta de creencias religiosas, lo que, finalmente, acabó por desvirtuar sus fundamentos más esenciales. Bertran critica así la ley del contraste y la ausencia de reglas, lo que permite al artista inspirarse en todos los elementos de la naturaleza, incluso en los más horribles y grotescos —de ahí la estética "de lo feo". Con relación a este aspecto, denuncia también que esta visión del romanticismo no tenga en cuenta ni la moral ni la religión cristianas, fundamentos esenciales del movimiento primitivo. Bertran afirma, "podrá defenderse un arte indiferente, pagano ó materialista y hasta concupiscente; lo que no podrá decirse es que semejante arte nazca del cristianismo". ${ }^{66}$

En posición similar sitúa a Théophile Gautier (I8II-I872), a quien Bertran reprocha el hecho de hablar de lirismo y de afán de pasión, así como de desarrollar libremente todos los caprichos del pensamiento, sin seguir ninguna regla o conveniencia. Dentro de la misma tendencia, el académico también sitúa la "fiebre ardorosa de desesperación y la ira atea de Byron", así como el arte sensualista y colorista de Théodore Géricault (I79I-I824), Gustave Courbet (I819-I877), Jean-Léon Gérôme (I824-1904) y Eugène Delacroix (I798-I863), "melenudos, extravagantes e infatuados". Estos artistas, seguidores de las teorías de Victor Hugo, han llevado el arte a un exceso de dramatismo a fin de alcanzar el "paroxismo de la pasión", a los sentimientos exasperados y a las "ideas malsanas". Esta derivación del romanticismo original, que Bertran llama "neorromanticismo" se encuentra sustentado sobre la base del escepticismo, del todo contrario a la moral cristiana y, según el autor, ha ido corrompiendo el arte de los últimos años, como lo muestran las manifestaciones artísticas de los "impresionistas" o de los "minoristas". De esta manera observamos hasta qué punto considera que, en los límites de su evolución, el movimiento habría terminado por desvirtuarse y enlazaría con determinadas tendencias de finales de siglo.

En conclusión, es clara la aceptación, por parte de la Academia, de corrientes estéticas vinculadas al romanticismo, al idealismo, y al simbolismo, pese a que determinadas figuras, como el mismo Bertran o Torras i Bages, pusieran ciertos límites de carácter moral y religioso a dicha aceptación. La vertiente

66. Bertran, Del origen y doctrinas, 2I. Los pasajes de Bertran citados a continuación corresponden a esta obra y página. 
DOI: http://dx.doi.org/10.22201/iie.18703062e.2017.1.2592.

I44

IRENE GRAS Y CRISTINA RODRÍGUEZ

del simbolismo que se propugnó desde la Academia fue básicamente idealista, con un fuerte rasgo romántico y estrechamente vinculada con lo nazareno.

Alumnos destacados de la escuela dependiente de la Academia de Bellas Artes de Barcelona desarrollaron proyectos escultóricos cercanos a los principios defendidos por Bertran y por Josep Maria Tamburini, cuyo discurso analizaremos a profundidad un poco más adelante. En el seno de esta Escuela se formaron los grandes artífices del modernismo escultórico educados en Barcelona. Un caso muy significativo es el de Josep Llimona (I863-I934), artífice ineludible de la escultura simbolista, quien cursó sus estudios en la institución entre I875 y I879. Del cincel de Llimona son los proyectos públicos más conocidos del movimiento, como el Monumento al Dr. Robert (I9O2-I9IO) (fig. I) o Desconsuelo (original de 1903, colocación 1917). El sentimentalismo introspectivo, la emoción contenida y el ritmo poético de sus obras públicas gozan de la misma intensidad que la que hallamos en otras propuestas anteriores del autor, como Modestia (1891) y Primera comunión (I897). Curiosamente, Llimona compartió mentor con otro escultor modernista, el ya mencionado Enric Clarasó (I857-194I), quien no dispone de demasiada obra sita en el espacio público en torno a 1900, pero fue el responsable de joyas como Eva (1904), además de las comentadas anteriormente en este artículo. Llimona y Clarasó se formaron junto al profesor de la Academia Joan Roig i Solé (I835-1918), quien impartió la asignatura de Escultura brevemente, entre i871 y $1877 .{ }^{67}$ Roig i Solé es recordado por su original estatua Dama del paraguas (I884), en la que propone una nueva forma de representar a la mujer contemporánea en la escultura pública, lejos de patrones iconográficos convencionales, con una sensibilidad afín al modernismo pese a su temprana cronología.

Otro de los egresados de la escuela que profesó una visión del simbolismo cercana a la de Bertran es Eusebi Arnau (I863-1933), quien estudió en el centro entre I878 y I885, bajo la tutela de Agapit Vallmitjana i Berbany (I8321905). Arnau es autor de maravillas de la escultura art nouveau internacional, como las musas del Palau de la Música Catalana, pero también de otras piezas menos célebres, en el espacio público. Es el caso de la delicada Devociones $y$ leyendas (I90I), conjunto de cuatro grupos de escultura aplicada a la fachada principal de un edificio de Enric Sagnier o Las nuevas tecnologias (1905),

67. Para mayores detalles sobre plantel de profesores, véase la visualización interactiva: "Professors i assignatures de l'Escola de Belles Arts de Barcelona (I850-1900)", consultado el 23 de octubre de 20I6, http://www.ub.edu/gracmon/docs/professors-llotja/. 


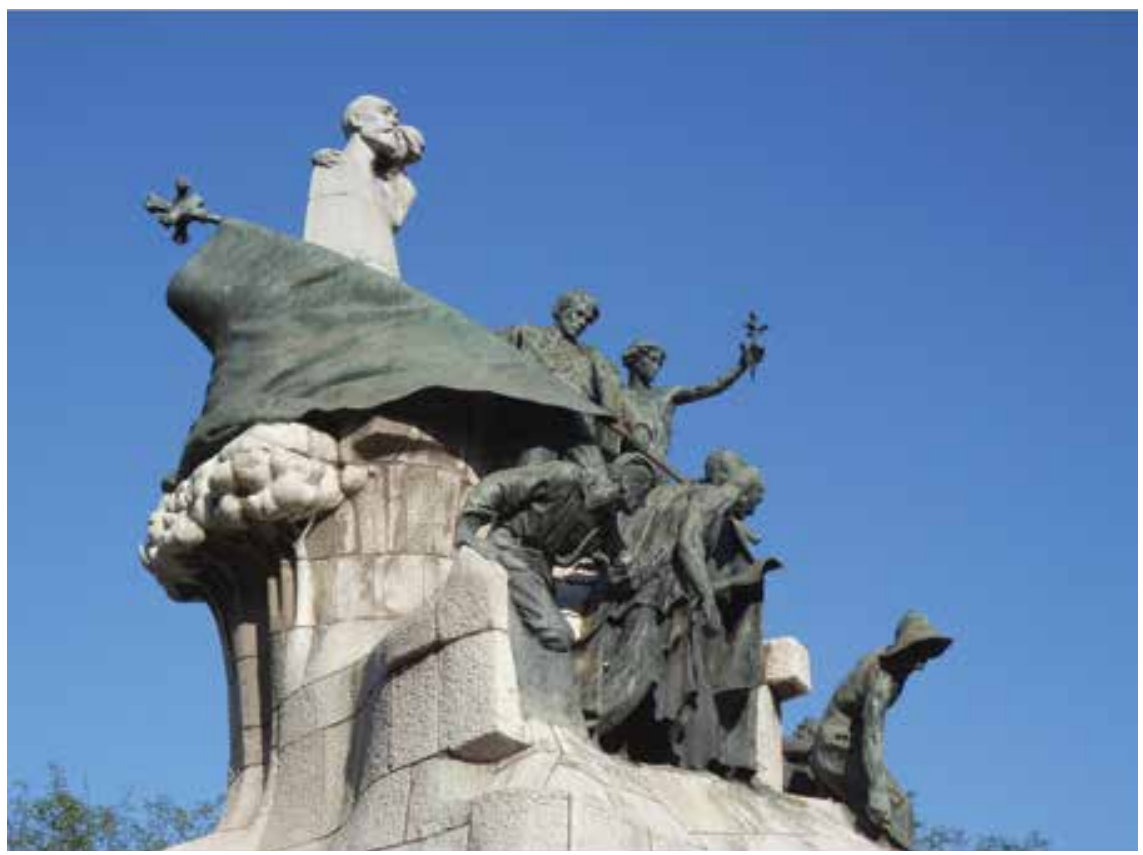

I. Josep Llimona, detalle del monumento al Dr. Robert (I902-1910). Foto: Camille Hardy.

figuras femeninas en relieve que cantan a la modernidad, en el céntrico edificio que Domènech i Muntaner diseñó para la familia Lleó Morera, para mencionar sólo algunas de sus esculturas consideradas modernistas (fig. 2).

$\mathrm{Al}$ observar las composiciones de estos escultores, resulta evidente que su lectura del simbolismo se realizó siempre desde la contención y que su visión no está exenta de cierto conservadurismo, máxime en los proyectos destinados al espacio público. Quizá puede apreciarse una mayor eclosión emotiva en la escultura funeraria, justificada por la naturaleza de esta disciplina. Incluso en piezas tan contundentes en lo relativo a la intensidad de su mensaje político como Rafael Casanova (I888) de Rossend Nobas (I849-I89I), la importancia de lo ético es fundamental. Nobas, alumno de la escuela de la Academia desde I856 hasta I860, que coincide con el inicio de la docencia de Andreu Aleu (I8321900), participó de las preocupaciones morales que integraban la escultura española del siglo, que rebasaron la frontera de 1900, y fueron fundamentales en la época modernista. El debate en torno a la ética y a la moral en el arte vertebra también los discursos académicos, como veremos a continuación. 
DOI: http://dx.doi.org/10.22201/iie.18703062e.2017.1.2592.

146

IRENE GRAS Y CRISTINA RODRÍGUEZ

\section{Moral y ética en el arte público}

Resulta evidente que, entre las ideas más debatidas en la época, destaca la de la conveniencia de la moralidad en el arte. Se trata de una discusión antigua, con una gran capacidad de pervivencia, puesto que lo que plantea, en definitiva, es la adecuación de la estética a la ética y, por tanto, es adaptable y flexible en función de los contextos históricos y sociales. Son varios los autores que abogan por la necesidad de la moralidad en el arte: lo hacen Tiberio Ávila (I8431932) en su discurso de $1896,{ }^{68}$ Antoni Rovira i Rabassa (I845-1919) en I89869 y General Guitart i Lostaló (I859-1926) en 1905 . $^{70}$ Sin embargo, ninguno de ellos desarrolla la idea como el ya citado escultor Pere Carbonell. Deudor de Ruskin, Carbonell entiende que el arte de cada raza, de cada pueblo, debe traducir exactamente su religión, clima, vida material y, sobre todo, moral. ${ }^{1 \mathrm{I}}$ Los griegos, a juicio del autor, fueron los primeros en conseguirlo en la escultura, aunque todavía no lo hicieran dentro de la esfera cristiana. ${ }^{72} \mathrm{El}$ programa iconográfico en la decoración escultórica de la Exposición de I888 evidenció el eco que estas ideas tenían, ya desde finales del siglo XIX, entre los artistas: se hace evidente en la elección de temas, su enfoque nacional y su tratamiento neutro y solemne.

La necesidad de que el arte y, en particular el arte público, fuera edificante y transmitiera ejemplos dirigidos a la mejora y prosperidad sociales es muy característico del siglo xix y continúa hasta el primer tercio del xx. En los discursos, estas ideas también se hicieron extensivas a la escultura aplicada y decorativa.

68. AРВBAAB, Consejos dirigidos á los alumnos premiados por el académico profesor numerario de la Escuela Oficial de Bellas Artes Dr. D. Tiberio Ávila y Rodriguez en la sesión pública celebrada el 27 de diciembre de I896 (Barcelona: Imprenta Barcelonesa, I896). Sobre Tiberio Ávila como docente de la Escuela de Bellas Artes, véase Cristina Rodríguez Samaniego, "L'Anatomia artística a l'Escola de Belles Arts de Barcelona. Els casos de Jeroni Faraudo (I823-I886) i de Tiberio Ávila (I843-I932)", Butlletí de la Reial Acadèmia Catalana de Belles Arts de Sant Jordi, RACBASJ, núm. 26 (20I2), consultado el I5 de mayo, 20I6, http://www.raco.cat/index.php/ButlletiraCBASJ/article/view/264088.

69. АРвваАВ, Consideraciones sobre los elementos que influyen en la decoración arquitectónica. Discurso leído por D. Antonio Rovira y Rabassa Arquitecto y académicos en la sesión pública celebrada el día 29 de diciembre de I898 (Barcelona: Imprenta Barcelonesa, I898).

70. АрвваАв, Consejos dirigidos á los alumnos Premiados por el profesor numerario de la Escuela Superior de Artes é Industrias y Bellas Artes. D. General Guitart y Lostaló en la sesión pública celebrada el I6 de abril de I905 (Barcelona: Imprenta Barcelonesa, 1905).

7I. АРвВААВ, Consejos dirigidos á los alumnos, 6.

72. АРвваАв, Consejos dirigidos á los alumnos, 8. 
2. Casa Lleó Morera, obra de Lluís

Domènech i Montaner (1902), ubicada en Paseo de Gracia, 35, Barcelona. Detalle de una escultura alegórica de la fotografía, obra de Eusebi Arnau, situada en el primer piso. Foto: Amadalvarez.

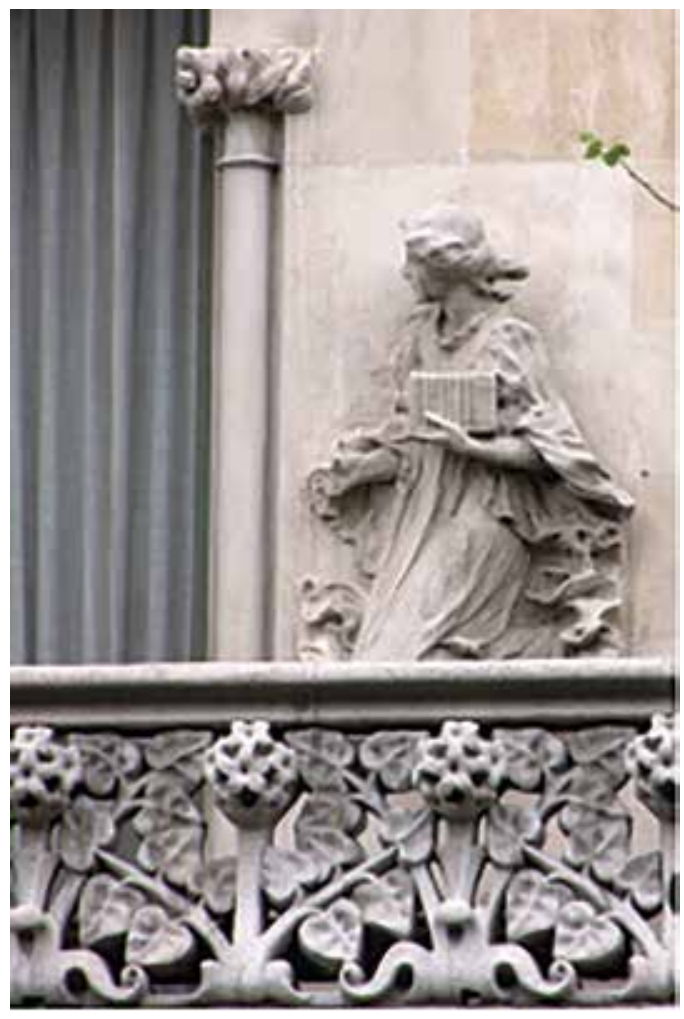

En términos generales, durante el periodo que nos ocupa, desde la Academia se abogaba por la mesura el énfasis decorativo de la escultura aplicada, y del ornamento artístico en general. El arquitecto Antoni Rovira i Rabassa (I845-1919) centró su discurso de I898 en la decoración arquitectónica, que él consideraba uno de los medios de expresión de la arquitectura, la primera y más importante de las artes, puesto que, a su juicio, resumía a la perfección idea y naturaleza. Rovira consideraba que, a la hora de plantear un edificio, después de concebirlo y darle forma plástica (procesos que él llamaba "distribución” y "construcción”, respectivamente), había que pensar en la decoración y en el ornamento, entre los que establecía una distinción. La decoración consistiría en elementos tales como ménsulas, arquivoltas, entre otros, que para Rovira son necesarios, porque "da lugar en los detalles, á inagotable manantial de bellos e inspirados contornos, dependiendo del cuerpo que deben revestir, y al cual atenúan su pesadez y 
DOI: http://dx.doi.org/10.22201/iie.18703062e.2017.1.2592.

\section{I48 IRENE GRAS Y CRISTINA RODRÍGUEZ}

rudeza, haciendo que sus formas sean más sensibles, atractivas y racionales, las cuales conspiran todas al buen efecto, imprimiendo á la vez el sello característico, que patentiza el final y destino utilitario del ser arquitectónico". ${ }^{73}$

El ornamento, que él entiende como escultura aplicada, no es indispensable y debe utilizarse con mesura, sólo donde sea necesario compensar un exceso de superficies planas. Es un recurso decorativo, independiente de la estructura, pero que a veces la puede poner de manifiesto. Se trata de un accesorio, que toca a la parte material de la arquitectura. ${ }^{74}$ Descubrimos un mismo énfasis en la necesidad de evitar la decoración superflua en los discursos de otros académicos del momento, como el de General Guitart i Lostaló (I859-1926).75 Una de las funciones de la decoración y del ornamento, según Rovira i Rabassa, es la de revestir las formas sin esconder la estructura, para evitar enseñar la crudeza excesiva del material. ${ }^{76}$ En este sentido, se aleja de lo que indicó al respecto Antoni Parera Saurina (I868-1946), gran admirador de la arquitectura de raíz industrial procedente de Europa y que en su discurso de 1906, dirigido a los alumnos becados, exhortó a conocer y a tratar de superar. ${ }^{77}$ Parera defendía una decoración escultórica que se adaptara a la función del espacio o elemento para el que estaba pensada, y que no fuera en detrimento de su practicidad. Se trata de un planteamiento que puede sorprender por su modernidad.

\section{Variedad de posturas y permeabilidad en la Academia}

Las consideraciones de los académicos profesores en torno al estado actual de las artes y del papel que en éstas debía jugar el artista son las que presentan posicionamientos más interesantes para demostrar la riqueza de criterios que caracterizaba el mundo académico en la Barcelona de 1900. En este sentido, vale la pena insistir en el rechazo que muchos de ellos hicieron del convencionalismo en el arte y, en concreto, del peso de la estética neoclásica en la escultura, incluso los más conservadores. Pere Carbonell, por ejemplo, lamentaba la existencia de esculturas que se limitaban a copiar las formas clásicas y, en especial, las que representaban desnudos femeninos de temática mitológica. A su juicio, no eran más

73. АРвBAAB, Consideraciones sobre los elementos, Iо.

74. АРВВААВ, Consideraciones sobre los elementos, II-I2.

75. АРвваAв, Consejos dirigidos á los alumnos, 7.

76. АРвВаАв, Consideraciones sobre los elementos, го.

77. АРвваАв, Consejos dirigidos á los alumnos, 5 . 
que formas vacías y abstractas que, además, desgraciadamente sólo expresaban sensualidad..$^{7} \mathrm{El}$ ideario de Carbonell se acercaba al del propio obispo Torras i Bages — quien también era académico—, tal y como ponen de manifiesto los propósitos que expuso este último a su discurso de 1896.79 Efectivamente, Torras i Bages rehúye la estética de los contrarios, que permite la mezcla de lo bello, virtuoso o sublime, con lo grotesco, vicioso o terrible... a la vez que insiste en establecer "límites" en el disfrute estético, en el cultivo de la imaginación y de la fantasía, y en la expresión de la subjetividad por parte del artista. Sin embargo, cabría añadir que el obispo en realidad no criticaba los fundamentos de la corriente simbolista - esto es, su anhelo de trascendencia, y la importancia que confiere a la fantasía y a la expresión de los sentimientos-, sino que lo que denunciaba eran sus excesos. De manera que, pese a su anhelo de reconducir la vida artística hacia posiciones más moderadas, presididas por un espíritu sobrio y cristiano, su postura no era radical. ${ }^{80}$

Un sector de los académicos que ejercían de profesores de la Escuela de Bellas Artes en el periodo de construcción del modernismo se mostraba convencido de que el arte de su momento estaba en decadencia. Encabezan esta postura el mismo Pere Carbonell y Tiberio Ávila. Ambos coincidían en la defensa de una plástica que conjugara naturaleza e idea de forma equilibrada y, como hemos visto ya, una temperatura moral y pedagógica alta. Carbonell criticaba la falta de unidad del mundo en que vivía, y su exceso de espíritu crítico, que, a su juicio, disgregaba y transformaba el pasado. Veía el arte actual como plataforma para transmitir inquietudes y ya no convicciones. La escultura que le rodeaba debía juzgarse desde el punto de vista psicológico, porque reflejaba la inquietud atormentada de la actualidad, instintiva, sin el imperativo ético que, según el autor, debería tener. ${ }^{8 \mathrm{r}}$

Como docente de escultura, Carbonell inició su carrera en I890, después de muchos ańos entregado a su formación en la misma escuela (I868-I880) y fue discípulo de Aleu y Roig i Solé. En 1905, cuando fue nombrado académico y leyó su discurso, tenía tras de sí una carrera ya consolidada, creada en paralelo a la consolidación del modernismo, de carácter idealista, pero sin participar directamente del simbolismo de raíz francesa. Sin embargo, es responsable de

78. арвваAв, Discurso leido por el Académico D. Pedro Carbonell y Huguet, I3-I4.

79. арвваaв, Discurso leido por el académico Rdo. Dr. José Torras y Bages, Pbro. En la sesión pública celebrada el día 27 de diciembre de 1896 (Barcelona: Imprenta Barcelonesa, I896), I6-17.

80. Gras Valero y Freixa, "El pensament estètic", I44-I48.

8I. арвваAв, Discurso leido por el Académico D. Pedro Carbonell y Huguet, I4-I5. 
DOI: http://dx.doi.org/10.22201/iie.18703062e.2017.1.2592.

150

IRENE GRAS Y CRISTINA RODRÍGUEZ

algunas de las piezas esenciales del programa escultórico de la Exposición de I888, con obra en el Arco de triunfo (fig. 3), el Monumento a Colón y el Palacio de Justicia.

Otro grupo de profesores académicos mantenía una postura muy diferente a la encabezada por Carbonell. En primer lugar, hay que destacar al pintor Vicenç Climent i Navarro ( $c a$. I872-1923). Su discurso ${ }^{82}$ es relevante porque pone de manifiesto el debate entre modernidad y tradición que existía en el seno de la Escuela, y del que también eran partícipes los alumnos. Climent estaba consciente de que, desde algunos sectores de la sociedad y desde el propio alumnado, se proyectaba la idea de la Escuela como institución anticuada y que había perdido su utilidad. Precisaba que los estudiantes disconformes constituían un grupo reducido, pero con cualidades artísticas y, por este motivo, quería dejar claro que la variedad y riqueza de los docentes eran garantía para la independencia de los que se allí se formaban. Lejos de presentar una visión única y uniforme de la Escuela, Climent la describe como orgánica y permeable.

Josep Maria Tamburini i Dalmau (I856-1932) fue, sin duda, una de las personas que tenía en mente Climent cuando se refería a la diversidad de la Escuela. En su discurso de $1904,{ }^{83}$ Tamburini, que era pintor y también impartía clases en la institución, hablaba de un ideal, pero, en contraposición a los preceptos defendidos por Torras i Bages, éste no era único ni trascendente, alcanzable sólo a partir de reglas limitadoras sino esencialmente diverso y libre. Hay que recordar, antes de analizar con más detalle dicho discurso, que Tamburini se había iniciado en la corriente idealista a partir de la década de 1890 , atraído por el romanticismo de la hermandad prerrafaelita y el simbolismo que empezaban a llegar a Cataluña. El pintor supo así aprovechar los nuevos recursos estéticos para poder captar la naturaleza de manera subjetiva y cultivar una visión sentimental, sugestiva y amable, dotada de una fuerte carga simbólica y literaria. No resulta extraño, pues, que a su llegada a la Academia, Tamburini no sólo defendiera un arte de tipo ideal, sino que, como veremos, incluso hablara elogiosamente de determinadas corrientes simbolistas que habían sido criticadas con dureza por Torras i Bages. ${ }^{84}$

82. арвванв, Enseñanza y estudio de las Bellas Artes. Discurso leido por D. Vicente Climent y Navarro profesor y académico en la sesión pública celebrada el día 20 de enero de I9oI (Barcelona: Imprenta Barcelonesa, 190I).

83. арвваAв, El ideal artístico. Discurso leido por el académico de número D. José Maria Tamburini, en la sesión pública celebrada el día 28 de febrero de 1904 (Barcelona: Imprenta Barcelonesa, 1904).

84. Gras Valero y Freixa, "El pensament estètic", I49-I50. 


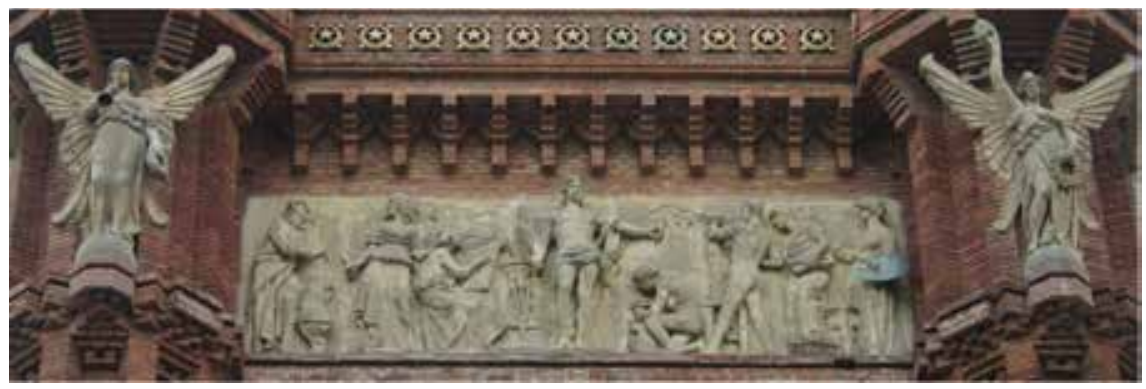

3. Pere Carbonell y Manel Fuxà, Famas aladas en los extremos del relieve de Torquat Tasso, Arco de Triunfo de Barcelona, I888. Foto: Yearofthedragon.

Asimismo, Tamburini hizo un alegato en favor de la individualidad y el temperamento del artista. Para él, el Arte en mayúsculas era, precisamente, lo que dejaba sentir el impulso y el carácter de quien había creado las academias. Para él, a diferencia de lo que pensaban Carbonell o Ávila, no existía un único ideal al que debían aspirar los artistas, sino que éste "es múltiple y vario como la naturaleza; libre como debe serlo el Arte". ${ }^{85}$ Tampoco había una visión única en el plantel de maestros de la Escuela, una falta de uniformidad que él consideraba necesaria para el buen desarrollo de las artes. ${ }^{86}$ Era muy claro en sus consejos a los artistas noveles: éstos no debían sacrificar sus propias iniciativas e intuiciones en función de lo que dictaban naturaleza y sociedad, ${ }^{87}$ sino que tenían que considerar imprescindibles tanto la imaginación como la sinceridad. ${ }^{88}$ Exhortaba a los artistas, de todas las disciplinas, a luchar por su perfeccionamiento, para desvincularse de elementos aprendidos o acercarse a influencias concretas que les ayudaran a exteriorizar elementos personales. Tamburini efectuaba un repaso a los movimientos y tendencias que consideraba interesantes, desde el paisajismo naturalista y el realismo de Courbet y Manet, hasta el simbolismo y el impresionismo, pasando por los prerrafaelitas. ${ }^{89}$ En cuanto al arte de su momento, el autor se mostraba optimista. Rechazaba el convencionalismo fruto del neoclasicismo que otros profesores académicos también habían criticado. ${ }^{90}$

85. АРВВААВ, El ideal artístico, IO.

86. АРВВААВ, El ideal artístico, 8.

87. АРВВААВ, El ideal artístico, 7.

88. АРВВААВ, El ideal artístico, 16.

89. АРВВААВ, El ideal artístico, I3-16.

90. АРвВААв, El ideal artístico, $\mathrm{I2}-\mathrm{I} 3$. 
DOI: http://dx.doi.org/10.22201/iie.18703062e.2017.1.2592.

I 52

IRENE GRAS Y CRISTINA RODRÍGUEZ

Del arte de su momento, Tamburini destacaba la capacidad de adaptación a las necesidades sociales y la convivencia de ideales distintos en su seno. Así, a su parecer persistían todavía las influencias de Diego Velázquez, mientras crecía el aprecio por Francisco de Goya (I746-I828) y por El Greco (I54I-I6I4), y se abrían paso el japonismo y el goticismo en la ornamentación. Finalmente, subrayaba como positivo el influjo del británico Aubrey Beardsley (I872-1898), los prerrafaelitas, el arte del siglo XviII o de pintores simbolistas como el suizo Arnold Böcklin (I827-I9OI). Todos ellos, presentados en su discurso como punto de partida para los jóvenes autores que querían singularizarse. ${ }^{91} \mathrm{La}$ pintura de Tamburini, caracterizada por un simbolismo de tipo idealista - o, utilizando las mencionadas palabras de Alexandre Cirici, de "ala blanca"-, muestra la influencia de estas tendencias.

El discurso de Josep Maria Tamburini apunta hacia una línea ideológica que pretende escapar de la tradición, de los convencionalismos y de las normas limitativas, al tiempo que se hace eco y promueve las corrientes innovadoras que en ese momento estaban en boga. En su afán de modernidad iría así mucho más lejos que Torras i Bages, aunque, como apunta Jaume Soler, ${ }^{92}$ su atrevimiento se manifestaba mucho más en el aspecto teórico que en su propia praxis artística. Cercano a este planteamiento, Antoni Parera compartía con Tamburini su creencia en la necesidad de que los artistas en formación exploraran libremente los estilos y las influencias. En su discurso, les recordaba que tan sólo ellos podían construir el carácter de sus obras, aunque les advertía contra los peligros del egotismo, que consideraba igualmente pernicioso..$^{93}$

Consideramos igualmente importante hacer referencia al discurso que hizo, en 1908, el arquitecto Manuel Vega i March (I87I-193I). Pese a que se escapa de los límites cronológicos que nos hemos marcado, no queremos dejar de mencionarlo, puesto que es testigo de cómo las ideas de Tamburini y Parera tuvieron continuidad. Vega, al referirse de nuevo a los alumnos becados, los exhortaba a no ser "modernistas, ni clásicos, ni románticos; no os agrupeis [sic] bajo etiquetas: sed simplemente artísticos: no os agrupeis [sic] bajo etiquetas; sed simplemente artistas: nutríos sin cesar de Conocimientos; no desdeñéis ninguna

9I. АРВВААВ, El ideal artístico, I7-I8.

92. Jaume Soler, Josep Maria Tamburini (Barcelona: Fundació Caixa de Barcelona, 1989), 17-18.

93. арвваАв, Consejos dirigidos por el profesor numerario de la Escuela Superior de Artes é Industrias y Bellas Artes D. Antonio Parera Saurina, 6 y 8. 
DOI: http://dx.doi.org/10.22201/iie.18703062e.2017.1.2592.

ESCULTURA，MODERNISMO Y ACADEMIA

fuente de belleza ni en las obras del hombre ni en las de la Creación”. ${ }^{94}$ Según Vega, el artista no debía dejarse influir por ninguna moda establecida o afán de imitación, sino que debía mantener una actitud abierta hacia la diversidad de tendencias existentes, ya que la variedad, tanto en el arte como en la naturaleza, enriquece al espíritu.

\section{Consideraciones finales}

En este artículo hemos tratado de contribuir al conocimiento de las artes en la época del modernismo. No nos centramos en el estudio del objeto, sino a partir de un corpus teórico procedente de la Academia de Bellas Artes de Barcelona, en la evolución de la disciplina a finales del siglo xIx; ahondamos en un tema poco tratado, arrojando luz sobre materiales poco conocidos y, en ocasiones, incluso de difícil acceso. En estos términos, la reflexión en torno a la evolución de la escultura del periodo nos permite aportar a la comprensión de los procesos mediante los cuales penetran las corrientes artísticas en el país, cómo son interpretadas y manejadas, y con qué filtros se transmiten a generaciones posteriores de artistas. Es innegable que la academia, en el caso barcelonés, ejerce gran influencia sobre la práctica y la docencia de las artes a finales del siglo xix, y que varios de los presupuestos que defiende también se encuentran concretados sobre piedra, en la escultura pública. Lo que propone este artículo es que dichos presupuestos, lejos de ser únicos, eran variados, heterogéneos, mutables, y que varios de ellos demostraban una clara apertura hacia las corrientes más innovadores y en boga de finales de siglo, como es el simbolismo. Y ello es sustancial, puesto que sustenta otra idea de lo que es la academia y el arte académico.

Conocer los discursos de los académicos de la Barcelona finisecular, sean profesores o no, es descubrir que en el seno de la academia convivían distintas voces, que defendían postulados a veces diametralmente opuestos. Y es también conocer cómo, a diferencia de lo que sostiene la historiografía más convencional, la mayor parte de académicos docentes denostaban el aprendizaje a través de la copia y exhortaban a sus alumnos a hallar una expresión propia. Es razonable suponer que dicho fenómeno no se limita a la Academia de Barce-

94. АРвваАв, El ideal artístico. Consejos dirigidos por el profesor auxiliar de la Escuela Superior de Artes é Industrias y Bellas Artes D. Manuel Vega y March en la sesión pública celebrada el 24 de mayo de I908 á los alumnos premiados con bolsa de viaje (Barcelona: Imprenta Barcelonesa, I908), 8. 
lona, sino que es probable que pueda demostrarse que otros centros, tanto en el contexto europeo como en el americano, no fueron ni uniformes ni estancos, sino universos vivos y permeables; en definitiva, que no sólo fueran susceptibles de recibir influencias, sino también de incidir en las manifestaciones artísticas menos tradicionales.

En la consolidación del lenguaje escultórico del modernismo, determinada por la confluencia de diversos factores, la Academia también jugó su papel. Esto se evidencia en la carrera y la obra de Josep Llimona, Eusebi Arnau y Rossend Nobas. Algunos académicos participaron en la importación de tendencias como el romanticismo nazareno, tal como refleja el análisis de la obra de Felip Bertran, o, más adelante, el simbolismo, a través de Josep Maria Tamburini. Ambas corrientes contribuyeron, en su confluencia, al modernismo. Por otro lado, resulta evidente que un sector preponderante de los profesores académicos defendieron un arte siempre a tono con una vocación ética y moral, en la que insisten Pere Carbonell o Tiberio Ávila, entre otros, y que representa un denominador común en el panorama escultórico de la época modernista, patente desde los proyectos religiosos, como en las estatuas de la Exposición Universal, y también en los monumentos conmemorativos. Otros académicos preconizaron la modernidad simplemente, al abogar por una sencillez compositiva y el abandono de fórmulas decorativas convencionales, como General Guitart. Precisamente, el abandono de las fórmulas del pasado es el factor en el que más coinciden los académicos del momento, sea cual fuere su ideología. Los discursos de los arquitectos, Rovira i Rabassa o Antoni Parera, permiten que entendamos los presupuestos que rigen la escultura aplicada modernista, al revestir las formas sin esconder totalmente la estructura —recordemos la importancia de materiales como el hierro y el cristal en el desarrollo de la arquitectura de la segunda mitad del siglo XIx.

Pese a que se escapa de los objetivos y alcances de este artículo al analizar con detalle la escultura modernista como objeto, confiamos en que los datos aquí expuestos, que responden al ámbito teórico, puedan alentar investigaciones posteriores que sobrepasen estos límites para adentrarse en otros campos $\mathrm{y}$ en otros espacios. \$

N.B. Este artículo contó con el apoyo del grupo de investigación GRACMON, de la Universitat de Barcelona, y se inscribe en el marco de su proyecto financiado "Mapa de los oficios de la escultura, I775-1936. Profesión, mercado e instituciones: de Barcelona a Iberoamérica” (MINECO HAR2OI3-437I5-P). 